\title{
Regimen Used to Treat Non-Hodgkin Lymphoma
}

National Cancer Institute

\section{Source}

National Cancer Institute. Regimen Used to Treat Non-Hodgkin Lymphoma. NCI

Thesaurus. Code C63442.

Any regimen that can be used for the treatment of non-Hodgkin lymphoma. 